\title{
OGRANICZENIA FUNKCJI KOMUNIKACYJNEJ OPAKOWAŃ PRODUKTÓW SPOŻYWCZYCH UŻYTKOWANYCH PRZEZ STARSZYCH KONSUMENTÓW ${ }^{3}$
}

\begin{abstract}
$\mathrm{Na}$ współczesnym, konkurencyjnym rynku produktów spożywczych szczególną rolę w zakresie komunikowania się z konsumentem pełni opakowanie. Opakowanie realizuje funkcję komunikacji głównie poprzez warstwę wizualną, na którą składają się znaki tworzące kod opakowania, tj. kształt, forma konstrukcyjna, materiał opakowaniowy, wielkość, rodzaj zamknięcia, barwa, napisy czy grafika. Na opakowaniach produktów spożywczych zamieszczane są znaki o charakterze fakultatywnym oraz znaki obligatoryjne, które muszą się znaleźć na opakowaniu ze względu na unormowania prawne. Przepisy prawa wskazują na zestaw informacji, jaki musi się znaleźć na opakowaniu produktu spożywczego oraz na ich fizyczny wygląd zapewniający czytelność, widoczność i zrozumiałość informacji. Spełnienie wymagań prawnych w zakresie fizycznego wyglądu informacji nie zawsze daje gwarancję właściwego pełnienia przez opakowanie funkcji komunikacyjnej. Ograniczeniem w tym zakresie mogą być np. specyficzne cechy konsumenta w starszym wieku, które utrudniają lub uniemożliwiają prawidłowe odszukanie, odczytanie i zrozumienie zamieszczanych na opakowaniach informacji. W artykule zaprezentowano wyniki badań dotyczące identyfikacji problemów starszych konsumentów z użytkowaniem opakowań produktów spożywczych. Szczególną uwagę zwrócono na najczęściej wskazywane przez starszych konsumentów problemy z informacyjnością opakowań w zakresie ich odnalezienia, odczytania i zrozumienia. Problemy starszych konsumentów z informacyjnością opakowań stanowią ograniczenia we właściwym pełnieniu przez opakowania funkcji komunikacyjnej. Badania przeprowadzono z wykorzystaniem dwóch metod: metody ankietowej oraz metody eyetracking. Analiza wyników badań pozwoliła na zidentyfikowanie źródeł problemów z wyszukiwaniem, odczytaniem i zrozumieniem informacji zamieszczanych na opakowaniach produktów spożywczych poprzez określenie problemów $\mathrm{z}$ informacyjnością opakowań w odniesieniu do cech opisujących respondentów a także poprzez percepcję poszczególnych elementów opakowania przez konsumentów w starszym wieku.

Słowa kluczowe: opakowanie, produkt spożywczy, starszy konsument, znakowanie, funkcja komunikacyjna
\end{abstract}

\footnotetext{
${ }^{1}$ Dr Jarosław Świda, Wydział Towaroznawstwa, Uniwersytet Ekonomiczny w Krakowie, ul. Rakowicka 27, 31-510 Kraków, swidaj@uek.krakow.pl, 12 293-51-65 (Author for correspondence)

${ }^{2}$ Dr Aldona Migała-Warchoł, Wydział Zarządzania, Katedra Metod Ilościowych, Politechnika Rzeszowska, al. Powstańców Warszawy 8, 35-959 Rzeszów, amigala@ prz.edu.pl, 17 865-16-02.

${ }^{3}$ Artykuł jest finansowany przez Narodowe Centrum Nauki, nr rejestracyjny projektu: 2014/13/B/HS4/00482.
} 


\section{WPROWADZENIE}

W warunkach rosnącego w ostatnich latach rynku spożywczego w Polsce, mierzonego wzrostem podaży produktów oraz ich zróżnicowaniem wzrasta rola komunikowania się przedsiębiorstw z potencjalnymi konsumentami. Bardzo ważną rolę w komunikowaniu się na konkurencyjnym rynku produktów spożywczych pełni opakowanie tworzące razem z produktem tzw. produkt zintegrowany. Produkt bowiem, z racji swego stanu skupienia bądź właściwości fizycznych lub chemicznych, jest inherentnie związany z opakowaniem, które towarzyszy mu w drodze do konsumenta ${ }^{4}$.

Istotą funkcji komunikacyjnej pełnionej przez opakowanie jest informacja przekazywana dla wielu celów (identyfikacji, sprzedaży, ostrzeżenia, właściwego użycia lub usuwania) poprzez możliwe drogi percepcji (wizualnie, dotykowo, słuchowo, węchowo i smakowo $)^{5}$. Opakowanie realizuje więc funkcję komunikacji poprzez nadaną mu celowo warstwę wizualną oraz wrażenia dotykowe, słuchowe, węchowe i smakowe. Warstwa wizualna opakowań jednostkowych produktów konsumpcyjnych jest nośnikiem zakodowanych

w określony sposób komunikatów znaczeniowych. Do podstawowych elementów składowych warstwy wizualnej opakowań, które określane są jako znaki tworzące kod opakowania należą: kształt, forma konstrukcyjna, materiał opakowaniowy, wielkość, rodzaj zamknięcia barwa opakowania, napisy, grafika i inne ${ }^{6}$.

Wśród znaków zamieszczanych na opakowaniach produktów spożywczych wyróżnić można znaki o charakterze fakultatywnym - są to znaki, które można nadać w dowolnej formie i ilości, a także obligatoryjnym - znaki, które koniecznie muszą się znaleźć na opakowaniu ze względu na unormowania prawne oraz które stanowią warunek wprowadzenia produktu na rynek.

Wymagania odnoszące się do konieczności zamieszczania różnych znaków na opakowaniu produktów pojawiają się w licznych aktach prawnych, jednak podstawowe kwestie w tym zakresie zostały określone w Rozporządzeniu Parlamentu Europejskiego i Rady UE nr 1169/2011 z 25 października 2011 roku w sprawie przekazywania konsumentom informacji na temat żywności.

Zgodnie z zasadami ogólnymi rozporządzenia w oznakowaniu produktu spożywczego obowiązkowe jest podanie kilku informacji, takich jak: nazwa produktu, wykaz składników wraz z zaznaczonymi w nim alergenami, ilość netto, data minimalnej trwałości lub termin przydatności do spożycia, warunki przechowywania lub warunki użycia, nazwa lub firma

i adres podmiotu odpowiedzialnego za informację na temat żywności oraz informacja o wartości odżywczej. Zgodnie z rozporządzeniem informacje na temat żywności muszą być rzetelne, jasne i łatwe do zrozumienia dla konsumenta. Ponadto informacje dotyczące żywności w opakowaniu powinny być oznaczone w sposób trwały i czytelny (wielkość czcionki nie mniejsza niż 1,2 mm). Tym samym rozporządzenie wprowadza definicję czytelności oznaczającej fizyczny wygląd informacji, dzięki któremu informacja jest wizualnie dostępna ogółowi społeczeństwa, a który określają różne elementy, m.in. rozmiar

\footnotetext{
${ }^{4}$ M. Lisińska-Kuśnierz, M. Ucherek, Opakowania w ochronie konsumenta, Wydawnictwo Akademii Ekonomicznej w Krakowie, Kraków 2006.

${ }^{5}$ H.E. Lockhard, A Paradigm for Packaging, "Packaging Technology and Science” 1997, 10(5), pp. $237-252$.

${ }^{6}$ J. Szymczak, M. Ankiel-Homa, Opakowanie jednostkowe produktów jako narzędzie komunikacji rynkowej, „Marketing i Rynek” 2007, nr 6, s. 16-20.
} 
czcionki, odstępy między literami, odstępy między wierszami, grubość linii pisma, barwa czcionki, rodzaj czcionki, stosunek szerokości liter do ich wysokości, powierzchnia materiału oraz kontrast między pismem a tłem.

Z punktu widzenia konieczności spełnienia pozostałych wymagań dotyczących widoczności i zrozumiałości informacji znajdujących się na opakowaniach produktów spożywczych pomocne mogą okazać się definicje zaproponowane przez M. LisińskąKuśnierz. Zgodnie z nimi widoczność znakowania: „określa stopień w jakim wygląd fizyczny informacji decyduje o dostrzeżeniu i znalezieniu treści przekazu przez ogół społeczeństwa,

a który określają elementy takie jak: rodzaj czcionki, wielkość czcionki, kontrast barwy tła i czcionki, barwa tła lub wielkość opakowania, jego forma konstrukcyjna i powierzchnia”. Natomiast zrozumiałość znakowania: „określa stopień w jakim wygląd fizyczny informacji decyduje o uporządkowaniu, spójności i odbiorze sensu komunikatu zgodnie z intencją nadawcy przez ogół społeczeństwa. Na zrozumiałość wpływ mają takie elementy znakowania jak np. nazwy łacińskie, kombinacje liter i liczb, zawiłe sformułowania, hasła, używanie niezrozumiałych słów, zbyt długie zdania, informacje prezentowane jednocześnie w kilku językach, dzielenie wyrazów, przesłanianie tekstu przez elementy graficzne" .

Spełnienie określonych wymogami prawa oraz powyższymi definicjami wymagań w zakresie czytelności, widoczności oraz zrozumiałości znaków zamieszczanych na opakowaniach produktów spożywczych decyduje o właściwym pełnieniu przez opakowanie funkcji komunikacji. Spełnienie wymagań prawnych oraz uwzględnienie powyższych definicji nie zawsze jednak daje gwarancję właściwego pełnienia przez opakowanie funkcji komunikacyjnej. Ograniczeniem w tym zakresie mogą być specyficzne cechy konsumenta, które utrudniają lub uniemożliwiają prawidłowe odszukanie, odczytanie i zrozumienie informacji zamieszczanych na opakowaniach. Do takiej szczególnej grupy konsumentów zaliczyć można konsumentów w starszym wieku. Zwrócenie uwagi na specyfikę tej grupy konsumentów wydaje się być celowe gdyż w wyniku zmian demograficznych liczba starszych konsumentów ciągle rośnie i w kolejnych latach będzie się zwiększać. W 2015 roku żyło w Polsce prawie 8,5 mln osób w wieku 60 lat i więcej Natomiast do 2050 roku spodziewany jest przyrost odsetka ludności w wieku 60 lat i więcej o prawie 19\%. W rezultacie udział osób starszych w populacji mieszkańców Polski zwiększy się z 21,5\% w $\quad 2013$ r. $(8,3 \mathrm{mln})$ do $40,4 \%(13,7 \mathrm{mln}) \mathrm{w}$ ostatnim roku prognozy ${ }^{8}$. Starsi konsumenci odgrywają na rynku coraz większa rolę, ich siła nabywcza wzrasta i stają się coraz bardziej liczącą się grupą odbiorców oferowanych na rynku towarów i usług ${ }^{9}$. Tym samym stają się coraz częściej podmiotem prowadzonych badań naukowych, również w zakresie wymagań i oczekiwań wobec opakowań produktów spożywczych ${ }^{10}$.

\footnotetext{
${ }^{7}$ M. Lisińska-Kuśnierz, Food packaging as non-satisfactory communication instrument in opinion of consumers, [w:] Innovations in Product Development and Packaging, red. A. Cholewa-Wójcik, A. Kawecka, Polskie Towarzystwo Towaroznawcze, Kraków 2014.

${ }^{8}$ Główny Urząd Statystyczny, 2016.

${ }^{9}$ M. Kulbaczewska, Starszy konsument na rynku turystyki uzdrowiskowej, Polskie Stowarzyszenie Zarządzania Wiedzą, Seria: Studia i Materiały, 2011, nr 50, s. 92-103.

${ }^{10}$ L. Duizer, T. Robertson J. Han, Requirements for Packaging from an Ageing Consumer's Perspective, "Packaging Technology and Science" 2009, 22, pp. 187-197; C. Hare, D. Kirk, T. Lang, Identifying the expectations
} 
Dostępne w polskiej literaturze badania oczekiwań konsumentów w zakresie informacji na opakowaniach dotyczą najczęściej wszystkich grup wiekowych respondentów ${ }^{11}$. Istotne więc wydaje się badanie konsumentów w starszym wieku w zakresie ich wymagań związanych z informacją zamieszczaną na opakowaniach produktów spożywczych.

Celem artykułu jest identyfikacja problemów starszych konsumentów związanych z informacjami przekazywanymi przez opakowanie produktów spożywczych stanowiących ograniczenia dla prawidłowego pełnienia przez opakowanie funkcji komunikacyjnej.

\section{METODYKA BADAŃ}

Badania zostały przeprowadzone z wykorzystaniem dwóch metod: metodą ankietową oraz metodą eyetracking.

Badania ankietowe zostały przeprowadzone w okresie listopad-grudzień 2015 roku w grupie 600 konsumentów w wieku 60 lat i więcej zamieszkujących teren województwa małopolskiego. Dobór próby miał charakter kwotowy i przedstawiał się następująco (tab. 1.)

Tabela 1. Populacja badanych respondentów

\begin{tabular}{|c|c|c|c|c|c|c|c|c|c|}
\hline & \multicolumn{2}{|c|}{ Wieś } & \multicolumn{2}{c|}{$\begin{array}{c}\text { Miasto } \\
\text { do 20 tys. }\end{array}$} & \multicolumn{2}{c|}{$\begin{array}{c}\text { Miasto } \\
\text { 20-200 tys. }\end{array}$} & \multicolumn{2}{c|}{ Kraków } & \\
\hline Wiek & $\mathrm{K}$ & $\mathrm{M}$ & $\mathrm{K}$ & $\mathrm{M}$ & $\mathrm{K}$ & $\mathrm{M}$ & $\mathrm{K}$ & $\mathrm{M}$ & Ogółem \\
\hline 60-69 lat & 75 & 64 & 20 & 16 & 32 & 25 & 47 & 35 & 314 \\
\hline 70-79 lat & 48 & 32 & 12 & 8 & 18 & 12 & 28 & 18 & 176 \\
\hline $\begin{array}{c}\text { 80 lat i } \\
\text { więcej }\end{array}$ & 35 & 16 & 8 & 3 & 12 & 5 & 21 & 10 & 110 \\
\hline Razem: & \multicolumn{2}{|c|}{270} & \multicolumn{2}{|c|}{67} & \multicolumn{2}{c|}{104} & \multicolumn{2}{c|}{159} & 600 \\
\hline
\end{tabular}

Źródło: opracowanie własne.

Badania zostały przeprowadzone metodą wywiadu kwestionariuszowego CATI. Kwestionariusz ankietowy składał się z dwóch części. Pierwsza z nich zawierała pytania dotyczące identyfikacji potrzeb i oczekiwań starszych konsumentów w odniesieniu do opakowań produktów spożywczych, m.in.: pytania o problemy, jakie zdarzają się starszym konsumentom w kontakcie z opakowaniem produktu spożywczego. Drugą część kwestionariusza ankietowego stanowiły pytania opisujące respondentów.

Analizę wyników badań ankietowych przeprowadzono z wykorzystaniem analizy korespondencji, która jest metodą łączącą redukcję wymiarów ocen obiektów oraz odzwierciedlenie na mapie percepcyjnej obiektów z uwzględnieniem ich wybranych $\operatorname{cech}^{12}$. Zaletą analizy korespondencji jest możliwość czytelnej, graficznej prezentacji współwystępowa-

of older food consumers, "Journal of Marketing Practice: Applied Marketing Science” 2009, 5 (6/7/8), pp. 213-232.

${ }^{11}$ R. Wierzejska, Informacje żywieniowe na opakowaniach produktów spożywczych - podejście konsumentów, „Przemysł Spożywczy” 2012, 66(5); G. Krasnowska, A.M. Salejda, Ocena wiedzy konsumentów na temat znakowania żywności, „Żywność. Nauka. Technologia. Jakość” 2011, 1(74), s. 173-189; M. TomaszewskaPielacha, I. Ozimek, Czytelność, zrozumiatość i kompletność informacji zamieszczanych na opakowaniach żywności w opinii konsumentów, „Problemy Higieny i Epidemiologii” 2011, 92(4), s. 820-823.

${ }^{12}$ A. Zaborski, Skalowanie wielowymiarowe $w$ badaniach marketingowych, Wydawnictwo. Akademii Ekonomicznej we Wrocławiu, Wrocław 2001, s. 30; K. Jajuga, Statystyczna analiza wielowymiarowa, PWN, Warszawa 1993; E. Gatnar, M. Walesiak, Metody statystycznej analizy wielowymiarowej w badaniach marketingowych, Wydawnictwo Akademii Ekonomicznej we Wrocławiu, Wrocław 2004. 
nia kategorii zmiennych ${ }^{13}$. Interpretacja otrzymanych wyników polega na ocenie położenia punktów obrazujących kategorie zmiennych na wykresie. W tym celu należy wziąć pod uwagę trzy elementy:

- położenie punktu wobec centrum rzutowania,

- położenie punktu względem innych punktów określających kategorie należące do tej samej cechy,

- położenie punktu względem punktu opisującego kategorię innej cechy ${ }^{14}$.

Metodologia analizy korespondencji opiera się na teście niezależności $\chi^{2}$. Test niezależności chi-kwadrat stosowany jest w przypadku badania niezależności cech niemierzalnych (jakościowych) lub w przypadku badania niezależności cechy jakościowej z ilościową ${ }^{15}$.

Badania metodą eyetracking przeprowadzono w czerwcu i lipcu 2016 roku wśród 60 celowo dobranych respondentów w wieku 60 lat i więcej.

Metoda eyetracking polega na śledzeniu ruchów gałek ocznych uczestników badania zapisując jednocześnie sakady (intensywne ruchy gałki ocznej, polegające na bardzo szybkim przemieszczaniu punktu koncentracji wzroku z jednego miejsca na inne) i fiksacje (relatywnie stała pozycja gałki ocznej, w trakcie której następują niewielkie drgania). Badanie to pozwala na określenie, w jaki sposób konsumenci postrzegają poszczególne elementy opakowania a więc umożliwiają poznanie percepcji wzrokowej potencjalnych konsumentów. Dzięki temu można się dowiedzieć m.in. na jakich obszarach skupia się wzrok konsumenta, a które są przez niego pomijane ${ }^{16}$. Badania przeprowadzono $\mathrm{z}$ wykorzystaniem eyetrackera Tobii rejestrującego ścieżkę patrzenia na zdjęciach wybranych marek mleka (Łaciate, Mlekovita, Zimne Mleko) wyświetlanych na ekranie monitora.

\section{WYNIKI BADAŃ I ICH OMÓWIENIE}

Wyniki badań ankietowych oraz eyetrackingowych dotyczących problemów z informacjami na opakowaniach produktów spożywczych wskazywanych przez starszych konsumentów zaprezentowano na rys. 1-6.

Wśród problemów z opakowaniami produktów spożywczych starsi konsumenci najczęściej wymieniali problemy $\mathrm{z}$ informacyjnością. Ponad połowa badanych osób $(10,8 \%$ odpowiedzi „zdecydowanie tak” oraz 40,1\% „raczej tak”) wskazała na problemy z odnalezieniem, odczytaniem i zrozumieniem informacji zamieszczonych na opakowaniu.

Dalsza analiza pozwala na szczegółową charakterystykę powiązań poszczególnych wymiarów informacyjności opakowań (odnalezienie, odczytanie i zrozumienie informacji) z cechami opisującymi badanych konsumentów.

W pierwszej kolejności weryfikowano hipotezę o niezależności cech, tj. każdego z analizowanych problemów z poszczególną kategorią z metryczki za pomocą testu niezależności chi-kwadrat. Hipotezę zerową o niezależności cech odrzucano, gdy wartość obli-

\footnotetext{
${ }^{13}$ A. Stanimir, Analiza korespondencji jako narzędzie do badania zjawisk ekonomicznych, wyd. Akademii Ekonomicznej we Wrocławiu, Wrocław 2005, s.7.

${ }^{14}$ A. Stanimir, op. cit., s. 76.

${ }^{15} \mathrm{~S}$. Mynarski, Analiza danych rynkowych i marketingowych z wykorzystaniem programu STATISTICA, Wydawnictwo. Akademii Ekonomicznej w Krakowie 2003.

${ }^{16}$ A. Duchowski, Eye Tracking Methodology. Theory and Practice, Springer, London 2007.
} 
czona statystyki chi-kwadrat przewyższała wartość krytyczną, przy założeniu, że została ona

odczytana dla wartości poziomu istotności bliskiej 0 . Wyniki obliczeń wraz z podaniem granicznych poziomów istotności przedstawiono w tabeli 2.

Rys. 1. Problemy z opakowaniami produktów spożywczych wskazywane przez starszych konsumentów

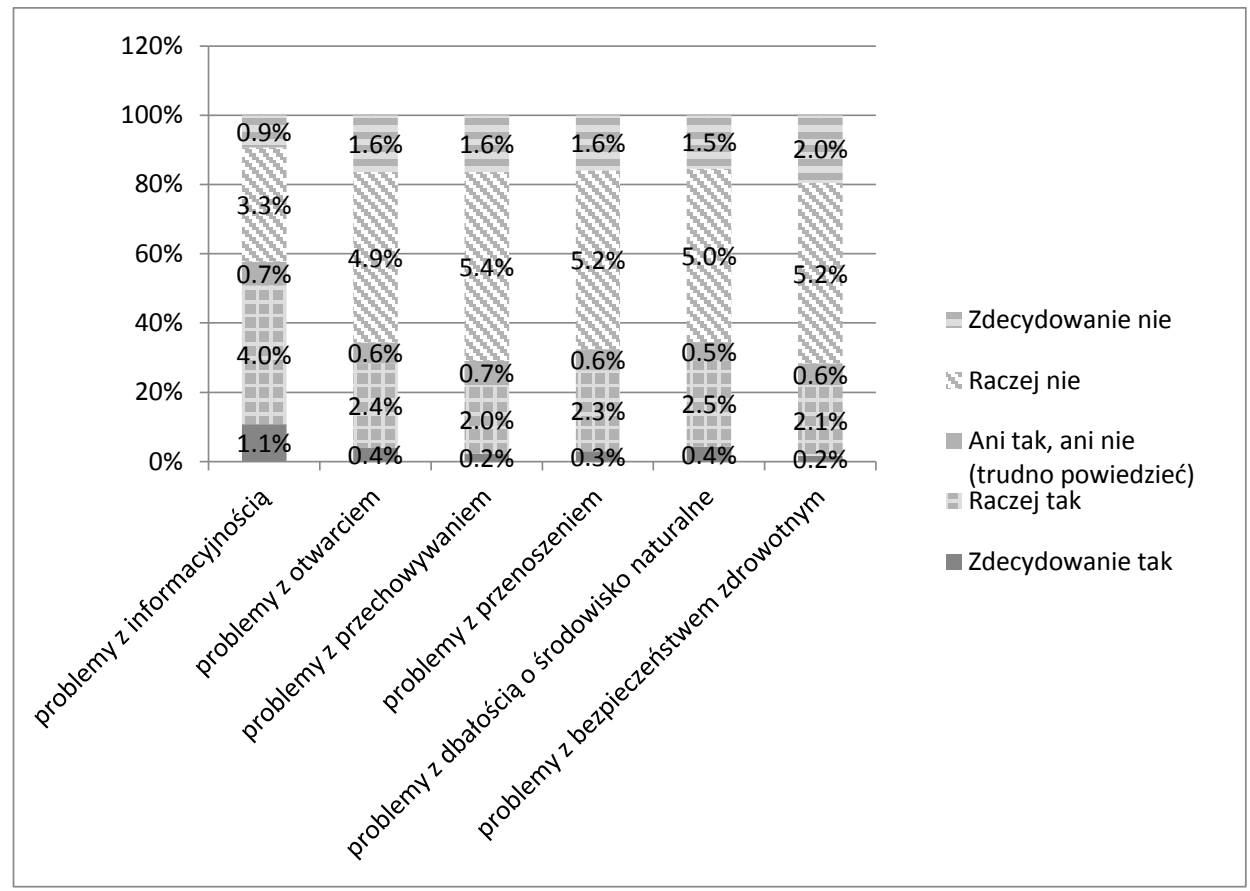

Źródło: badania własne.

Tabela 2. Wyniki testu niezależności chi-kwadrat (w nawiasach podano graniczne poziomy istotności)

\begin{tabular}{|c|c|c|c|c|}
\hline \multirow{2}{*}{ Problemy } & \multicolumn{4}{|c|}{ Wartości statystyki chi-kwadrat } \\
\cline { 2 - 5 } & Pleć & Wiek & Wyksztalcenie & $\begin{array}{c}\text { Miejsce zamiesz- } \\
\text { kania }\end{array}$ \\
\hline $\begin{array}{c}\text { Problem z odnalezie- } \\
\text { niem informacji }\end{array}$ & 7,33 & $\mathbf{1 3 , 4 3}$ & 15,38 & $\mathbf{2 5 , 6 9}$ \\
& $(0,12)$ & $(\mathbf{0 , 1})^{*}$ & $(0,22)$ & $\mathbf{( 0 , 0 1})^{* *}$ \\
\hline Problem z odczyta- & 4,03 & 9,71 & 13,47 & $\mathbf{2 7 , 3 8}$ \\
niem informacji & $(0,4)$ & $(0,29)$ & $(0,34)$ & $(\mathbf{0 , 0 1})^{* *}$ \\
\hline Problem ze zrozu- & 3,26 & $\mathbf{1 4 , 3 5}$ & $\mathbf{1 9 , 1 4}$ & 12,13 \\
mieniem informacji & $(0,52)$ & $\mathbf{( 0 , 1})^{*}$ & $(\mathbf{0 , 1}) *$ & $(0,44)$ \\
\hline
\end{tabular}

Źródło: opracowanie własne. 
Wartości, które zostały oznaczone jedną gwiazdką oznaczają statystycznie istotną wartość chi-kwadrat przy poziomie istotności 0,1 , natomiast dwie gwiazdki oznaczają statystycznie istotną wartość chi-kwadrat przy poziomie istotności 0,01 .

Oznacza to, iż między analizowanymi zmiennymi występują następujące zależności: między problemem $\mathrm{z}$ odnalezieniem informacji a wiekiem przy poziomie istotności 0,1 i miejscem zamieszkania przy poziomie istotności 0,01 , między problemem z odczytaniem informacji a miejscem zamieszkania przy poziomie istotności 0,01 i między problemem ze zrozumieniem informacji a wiekiem i wykształceniem przy poziomie istotności 0,1 .

W dalszym toku artykułu zaprezentowano wyniki analizy korespondencji wykonane za pomocą programu Statistica 12 dla problemów związanych z odnalezieniem, odczytaniem i zrozumieniem informacji i kategorii metryczkowych dla których uzyskano statystycznie istotną wartość statystyki chi-kwadrat.

Wszystkie wyniki zaprezentowano w dwuwymiarowym układzie, wyjaśniającym w każdym przypadku - ponad $90 \%$ bezwładności. Na rys. 2 przedstawiono prezentację powiązań kategorii Problem z odnalezieniem informacji i wieku respondentów.

W przypadku prezentacji powiązań kategorii Problem $z$ odnalezieniem informacji i wieku respondentów dwuwymiarowy obszar rzutowania pozwala wyjaśnić 100,00\% ogólnej bezwładności. Na rys. 2 widzimy, że oś pozioma, która ma największy udział w bezwładności, charakteryzuje się tym, że po prawej stronie względem środka osi znajdują się osoby, które raczej nie miały problemu z odnalezieniem informacji, natomiast po lewej stronie umiejscowione zostały osoby, które zdecydowanie miały problem z odnalezieniem informacji. Spośród punktów reprezentujących wiersze, najbardziej na lewo znajdują się osoby starsze - mające powyżej 80 lat, natomiast na prawo osoby młodsze mające 60 lat i więcej. Spostrzeżenia te sugerują, że większość bezwładności ogólnej wynika $\mathrm{z}$ różnic pomiędzy osobami mającymi problem z odnalezieniem informacji. Zdecydowane problemy

$\mathrm{z}$ odnalezieniem informacji miały najstarsze, ankietowane osoby w wieku 80 lat i więcej, natomiast osoby w wieku 60-69 raczej nie miały problemów z odnalezieniem informacji. Ciekawy okazał się fakt, iż osoby w wieku 70-79 lat stwierdziły, że zdecydowanie nie miały problemów z odnalezieniem informacji.

W przypadku prezentacji powiązań kategorii Problem $z$ odnalezieniem informacji i miejsca zamieszkania respondentów dwuwymiarowy obszar rzutowania pozwala wyjaśnić $97,43 \%$ ogólnej bezwładności. Z rys. 3 można odczytać, że mieszkańcy wsi raczej nie mają problemów z odnalezieniem informacji, mieszkańcy miast o liczbie mieszkańców 20-200 tys. zdecydowanie ich nie mają, natomiast mieszkańcy Krakowa raczej je mają. Mieszkańcy miast do 20 tys. nie określili swoich preferencji w tej kwestii.

W przypadku prezentacji powiązań kategorii Problem $z$ odczytaniem informacji i miejsca zamieszkania respondentów dwuwymiarowy obszar rzutowania pozwala wyjaśnić 99,95\% ogólnej bezwładności. Z rys. 4 można odczytać, że problemy z odczytaniem informacji mieli mieszkańcy Krakowa i miast liczących 20-200 tys. mieszkańców. Mieszkańcy wsi raczej nie mieli takich problemów. Mieszkańcy miast do 20 tys. nie określili swoich preferencji w tej kwestii. 
Rys. 2. Prezentacja powiązań kategorii Problem z odnalezieniem informacji i wieku respondentów

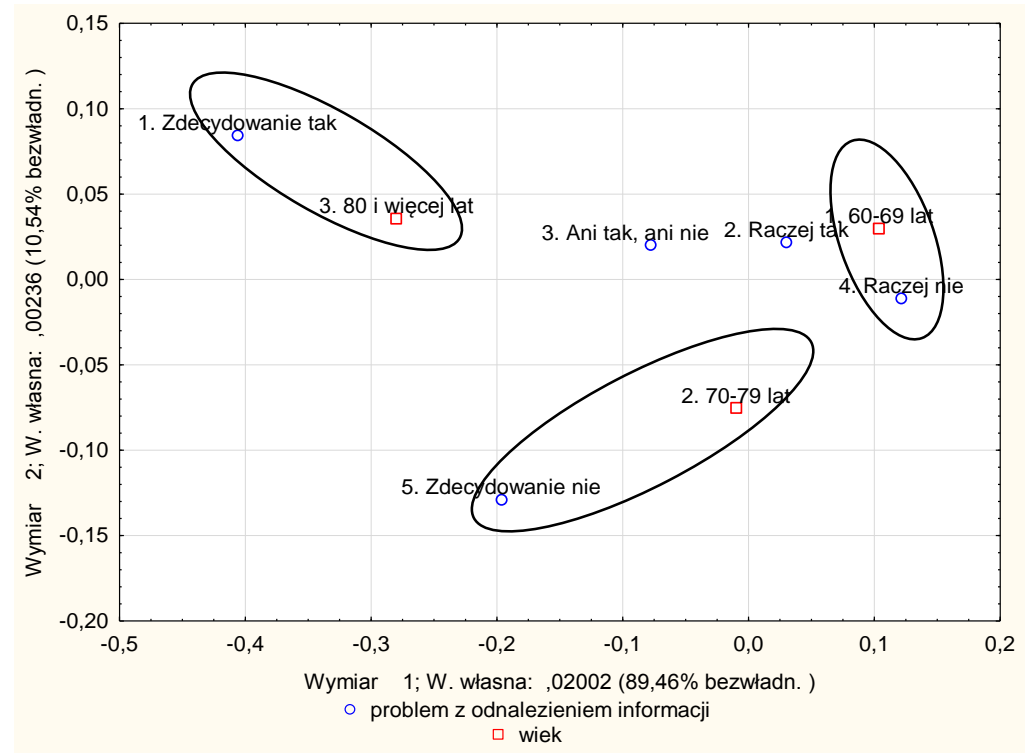

Źródło: opracowanie własne.

Rys. 3. Prezentacja powiązań kategorii Problem $z$ odnalezieniem informacji i miejsca zamieszkania respondentów

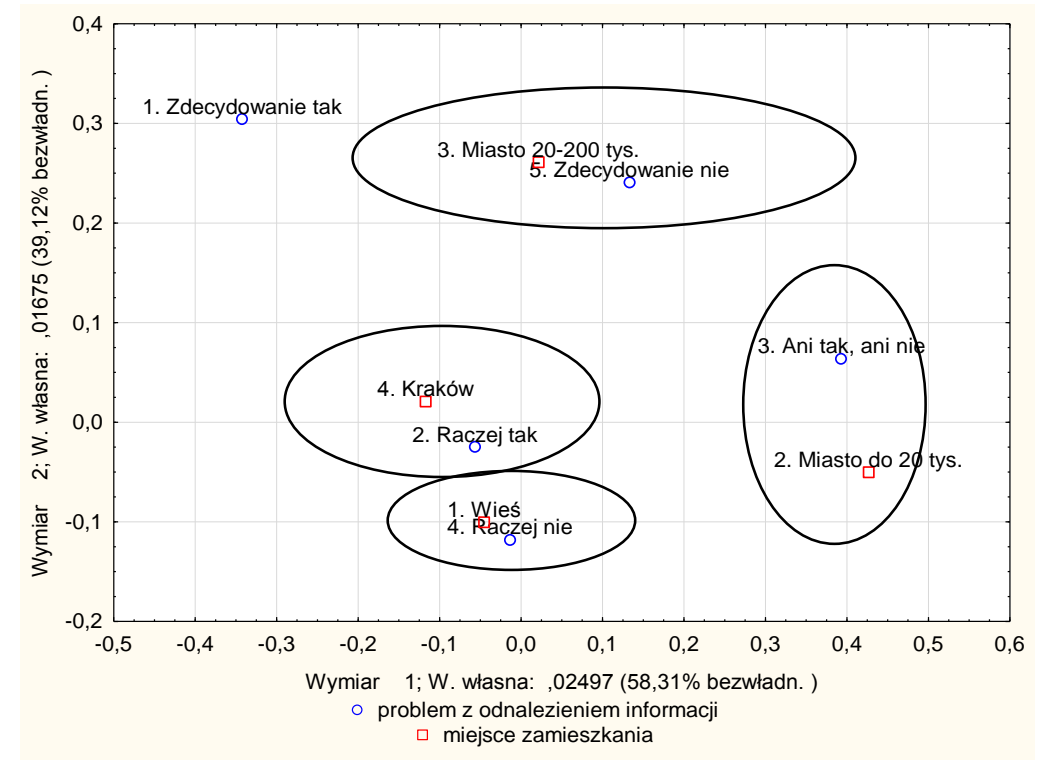


Źródło: opracowanie własne.

Rys. 4. Prezentacja powiązań kategorii Problem $z$ odczytaniem informacji i miejsca zamieszkania respondentów

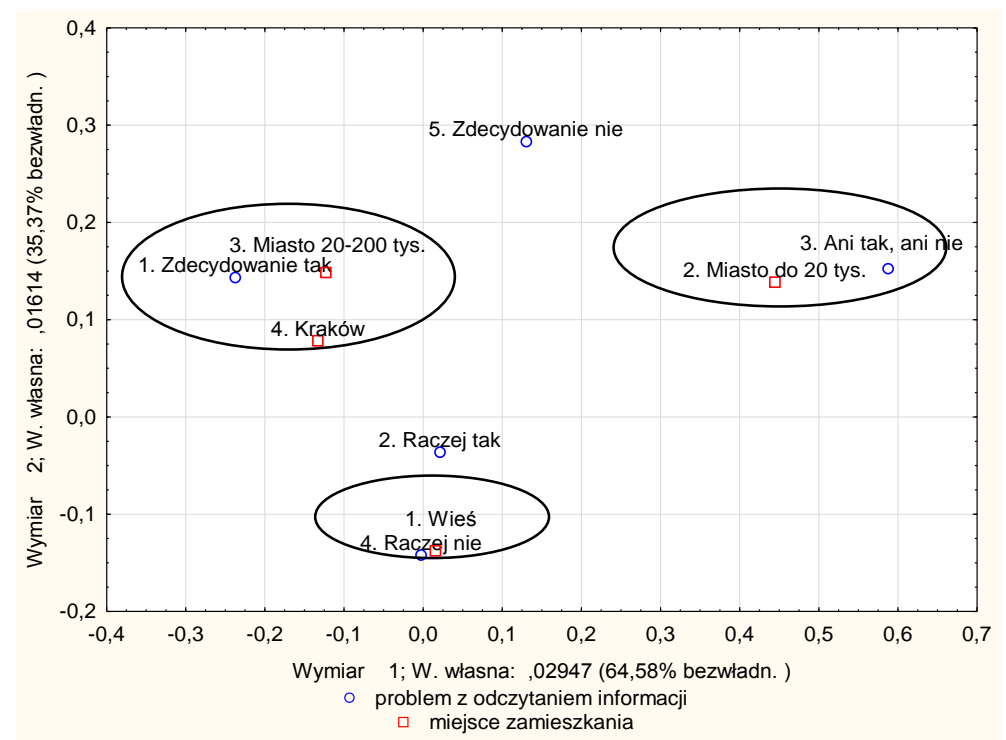

Źródło: opracowanie własne.

Rys. 5. Prezentacja powiązań kategorii Problem ze zrozumieniem informacji i wieku respondentów

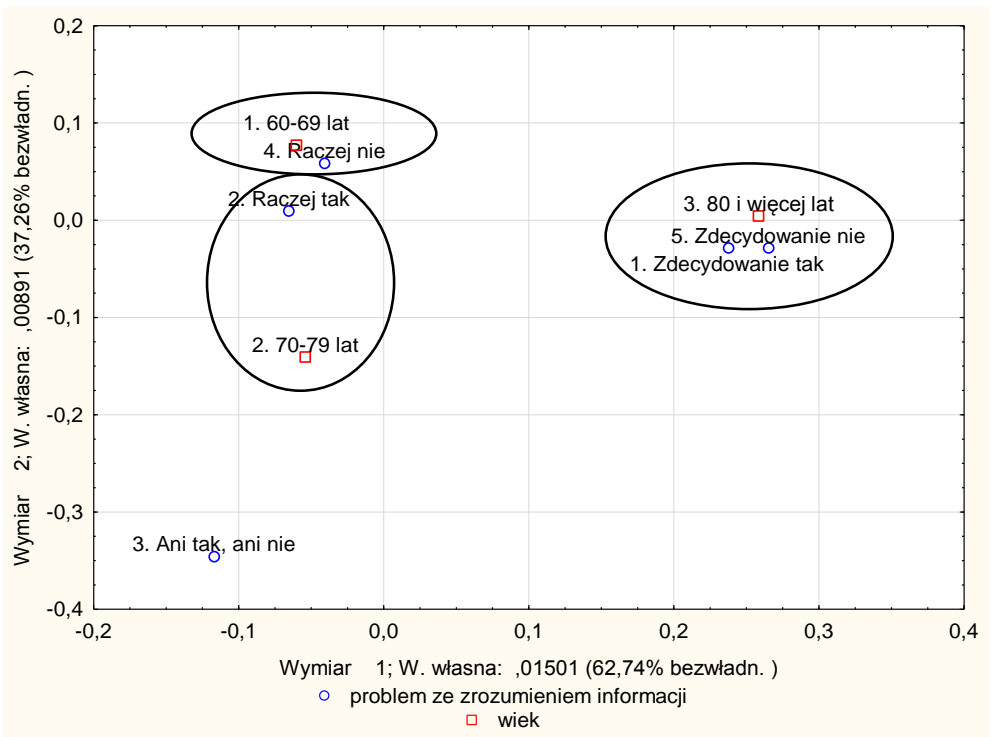

Źródło: opracowanie własne. 
W przypadku prezentacji powiązań kategorii Problem ze zrozumieniem informacji i wieku respondentów dwuwymiarowy obszar rzutowania pozwala wyjaśnić 100,00\% ogólnej bezwładności. Z rys. 5 można odczytać, że problemy ze zrozumieniem informacji raczej miały osoby w wieku 70-79 lat. Raczej ich nie miały osoby w wieku 60-69 lat. Respondenci w wieku powyżej 80 lat określili dwuznacznie tę kwestię, część z nich zdecydowanie je miała, a cześć zdecydowanie ich nie miała.

Rys. 6. Prezentacja powiązań kategorii Problem ze zrozumieniem informacji i wykształcenia respondentów

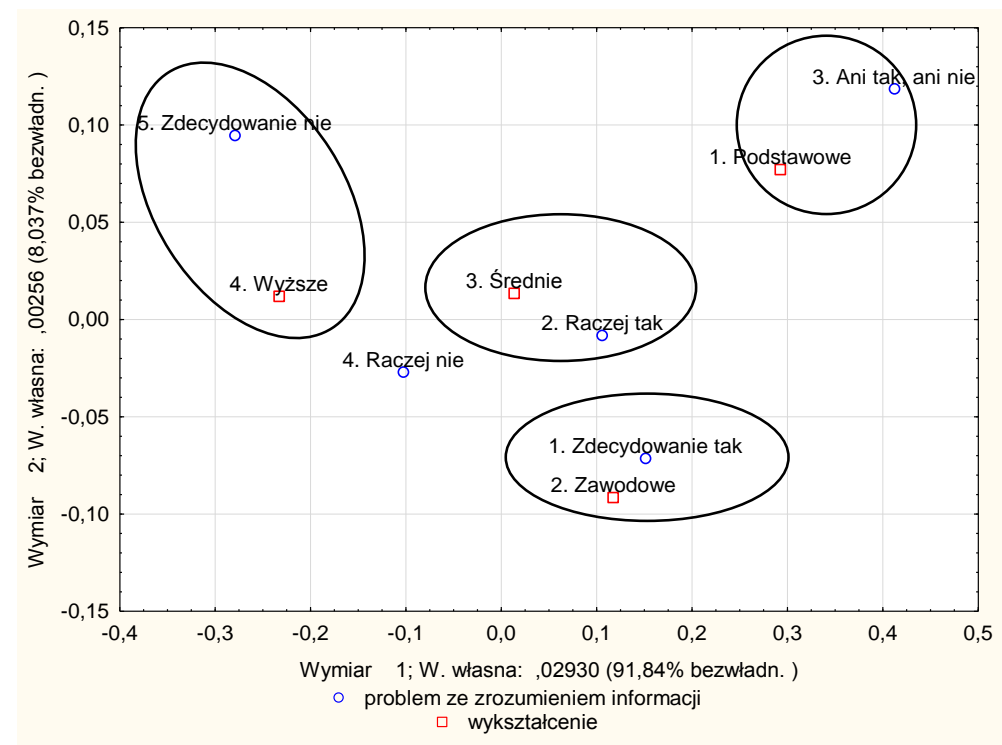

Źródło: opracowanie własne.

W przypadku prezentacji powiązań kategorii Problem ze zrozumieniem informacji i wykształcenia respondentów dwuwymiarowy obszar rzutowania pozwala wyjaśnić 99,88\% ogólnej bezwładności. Z rysunku 6 można odczytać, że problemy ze zrozumieniem informacji zdecydowanie miały osoby z wykształceniem zawodowym. Raczej je miały osoby $z$ wykształceniem średnim. Zdecydowanie ich nie miały osoby z wykształceniem wyższym. Respondenci z wykształceniem podstawowym nie określili swoich preferencji w tej kwestii.

Dodatkowych informacji na temat problemów starszych konsumentów z informacyjnością opakowań produktów spożywczych dostarczyły badania metodą eyetracking. Zadaniem konsumentów było wyszukiwanie informacji o terminie przydatności do spożycia oraz o składzie produktu na wybranych opakowaniach mleka. Wyniki badań zaprezentowano na rysunkach 7 i 8 . 
Rys. 7. Mapy cieplne obrazujące rozkład uwagi wzrokowej podczas wyszukiwania informacji o terminie przydatności do spożycia [suma długości fiksacji (skupień wzroku)] na poszczególnych elementach opakowania (najciemniejsze miejsca to te, na które respondenci patrzyli najdłużej)
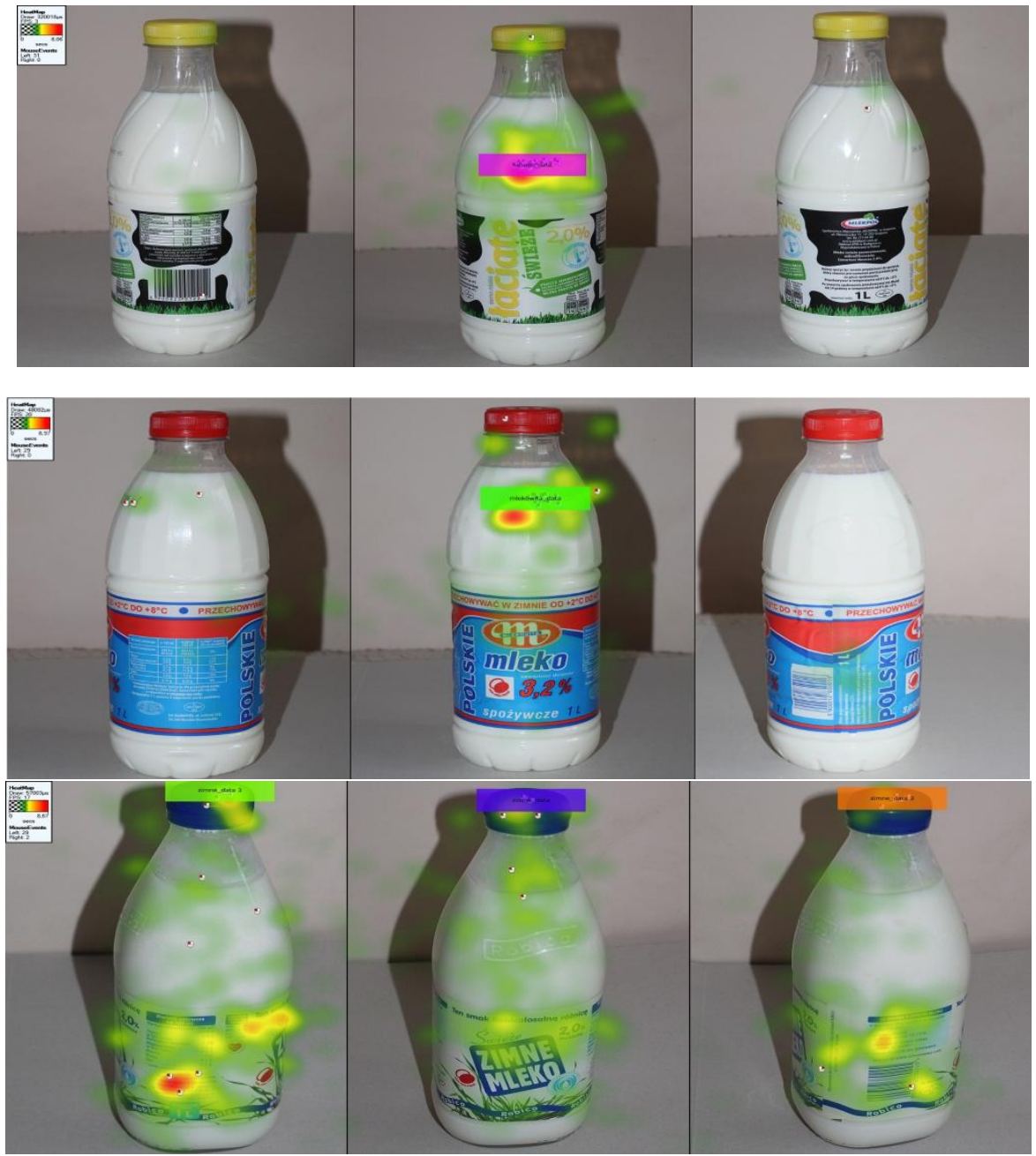

Źródło: badania własne.

Wyniki badań pokazują, iż uwaga wzrokowa badanych osób była najmniej rozproszona na opakowaniu mleka marki Mlekovita oraz mleka Łaciate - fiksacje odnotowano w większości tam gdzie znajduje się informacja o terminie przydatności do spożycia. Natomiast na opakowaniu mleka marki Zimne Mleko uwaga konsumentów była rozproszona - konsumenci poszukiwali informacji na opakowaniu (na etykiecie oraz na butelce) podczas gdy informacja umieszczona jest na zamknięciu opakowania. 
Rys. 8. Mapy cieplne obrazujące rozkład uwagi wzrokowej podczas wyszukiwania informacji o składzie produktu [suma długości fiksacji (skupień wzroku)] na poszczególnych elementach opakowania (najciemniejsze miejsca to te, na które respondenci patrzyli najdłużej)
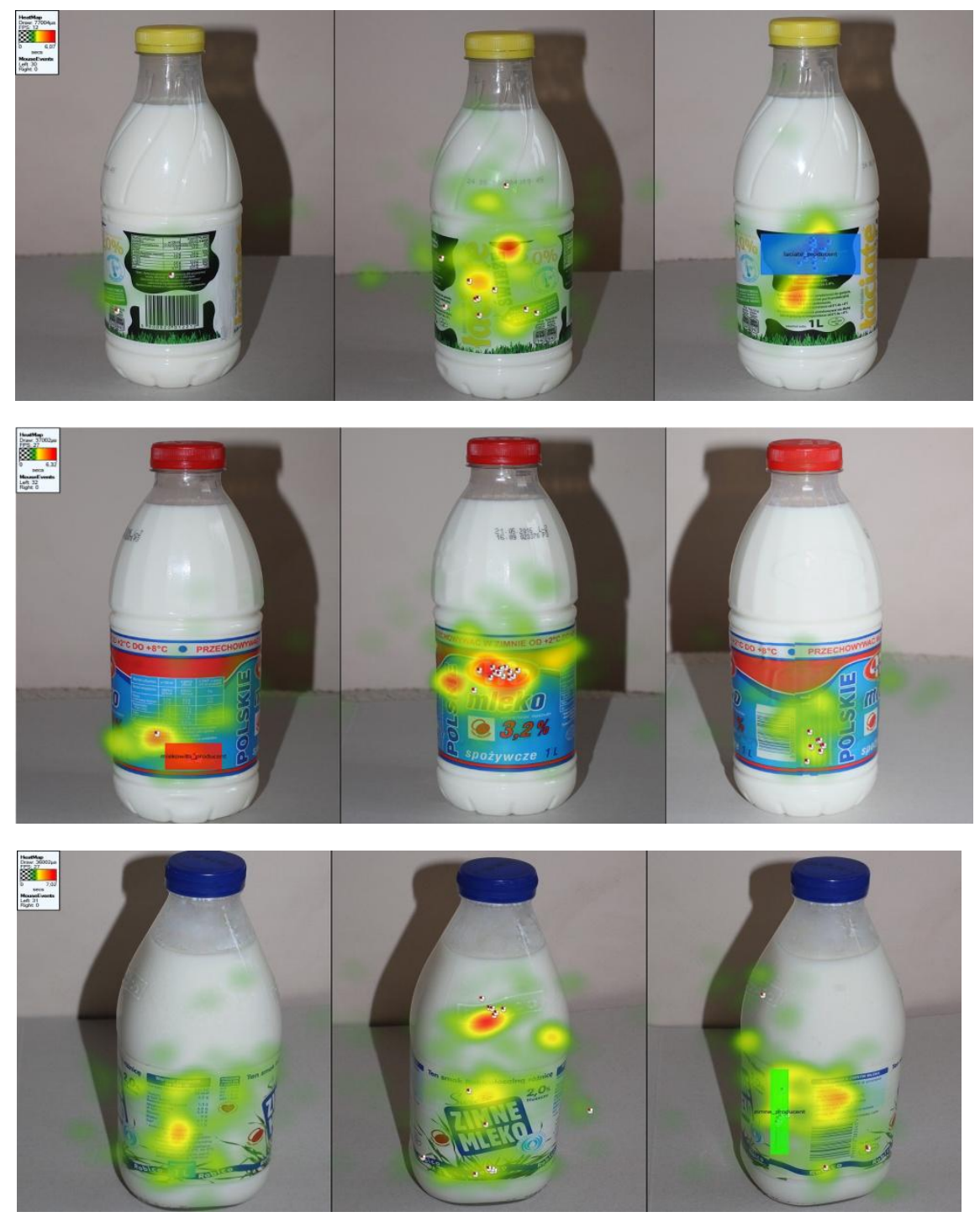

Źródło: badania własne.

W trakcie poszukiwania informacji o składzie produktu uwaga wzrokowa badanych osób skupiona była na etykietach zamieszczonych na opakowaniach i w przypadku opakowań mleka marki Łaciate oraz Mlekovita wskazania składu były prawidłowe. W przypadku mleka marki Zimne Mleko odnotowano wiele błędnych wskazań tej informacji. 


\section{PODSUMOWANIE}

Starzenie się społeczeństw generuje nowe wyzwania dla specjalistów ds. jakości, marketingu, czy rozwoju nowych produktów Segment starszych konsumentów będzie wzrastał w kolejnych latach, co oznacza konieczność wdrożenia specjalnych narzędzi marketingowych uwzględniających nawyki, potrzeby i oczekiwania tej grupy docelowej w odniesieniu do produktów i ich opakowań.

Opakowanie może odegrać szczególną rolę w dotarciu do starszych konsumentów poprzez właściwie pełnioną funkcję komunikacji. Właściwie pełniona przez opakowanie funkcja komunikacji oznacza umożliwienie konsumentom w starszym wieku szybkie i prawidłowe odnalezienie, odczytanie i zrozumienie informacji zamieszczonych na opakowaniach. Tymczasem przeprowadzone przez autorów artykułu badania wskazują na to, że największe problemy starszych z opakowaniami produktów spożywczych są związane $\mathrm{z}$ ich informacyjnością. Szczegółowa analiza wyników badań uwzględniająca powiązania informacyjności opakowań z cechami opisującymi konsumentów pozwala dodatkowo stwierdzić, że największe problemy z odnalezieniem informacji na opakowaniach produktów spożywczych mają osoby w wieku powyżej 80 lat mieszkający w Krakowie, natomiast największe problemy ze zrozumieniem zamieszczanych na opakowaniach informacji mają osoby w wieku powyżej 70 lat z wykształceniem zawodowym. Dodatkowym argumentem przemawiającym za zwróceniem szczególnej uwagi na najstarszych w grupie starszych konsumentów jest zjawisko tzw. podwójnego starzenia się polegające na szybszym niż ogółem tempie wzrostu odsetka ludności w wieku 80 i więcej lat. Według przewidywań GUS, osoby co najmniej 80 -letnie będą w 2050 r. stanowiły $10,4 \%$ populacji kraju, podczas gdy w $2013 \mathrm{r}$. było to zaledwie 3,9\%.

Przeprowadzone przez autorów artykułu badania metodą eyetracking pozwoliły na identyfikację problemów starszych konsumentów związanych z informacyjnością opakowań produktów spożywczych poprzez badanie uwagi wzrokowej na poszczególnych elementach opakowania. Wyniki badań potwierdziły problemy starszych konsumentów z wyszukiwaniem i zrozumieniem informacji na wybranych opakowaniach produktów spożywczych.

Poznanie szczególnych potrzeb, wymagań i oczekiwań starszych konsumentów w zakresie informacji zamieszczanych na opakowaniach produktów spożywczych jest szczególnie ważne dla dostosowania oferty produktowej skierowanej do tej grupy odbiorców. Prowadzenie badań w tym zakresie powinno być oparte na wiedzy dotyczącej specyficznych cech i wewnętrznego zróżnicowania grupy konsumentów w starszym wieku. Znakowanie produktów spożywczych umożliwiające starszym konsumentom prawidłowe odnalezienie, odczytanie i zrozumienie informacji zamieszczonych na opakowaniu jest ważnym czynnikiem wpływającym na decyzje zakupowe starszych konsumentów oraz co najważniejsze - elementem zapewnienia bezpieczeństwa spożycia produktu.

\section{LITERATURA}

[1] Duchowski A., Eye Tracking Methodology. Theory and Practice, Springer, London 2007.

[2] Duizer L., Robertson T., Han J., Requirements for Packaging from an Ageing Consumer's Perspective, "Packaging Technology and Science" 2009, 22.

[3] Hare C., Kirk D., Lang T., Identifying the expectations of older food consumers, "Journal of Marketing Practice: Applied Marketing Science" 1999, 5 (6/7/8). 
[4] Jajuga K., 1993, Statystyczna analiza wielowymiarowa, PWN, Warszawa 1993.

[5] Gatnar E., Walesiak M., Metody statystycznej analizy wielowymiarowej w badaniach marketingowych, Wydawnictwo Akademii Ekonomicznej we Wrocławiu, Wrocław 2004.

[6] Jerzyk E., Wymagania starszych konsumentów wobec opakowań jednostkowych, Marketing i Rynek” 2014, nr 6.

[7] Krasnowska G., Salejda A.M., Ocena wiedzy konsumentów na temat znakowania żywności, „Żywność. Nauka. Technologia. Jakość” 2011, 1 (74).

[8] Kulbaczewska M., Starszy konsument na rynku turystyki uzdrowiskowej, Polskie Stowarzyszenie Zarządzania Wiedzą Seria: Studia i Materiały, 2011, nr 50.

[9] Lisińska-Kuśnierz M., Food packaging as non-satisfactory communication instrument in opinion of consumers [in:] Innovations in Product Development and Packaging, red. A. Cholewa-Wójcik, A. Kawecka, Polskie Towarzystwo Towaroznawcze, UEK, Kraków 2014.

[10] Lisińska-Kuśnierz M., Kabaja B., Information inaccuracies in dietary suplement labeling as assesed by consumers. Food Product Quality and Packaging, Celje. University of Maribor, 2015.

[11] Lisińska-Kuśnierz M., Ucherek M., Opakowania w ochronie konsumenta, Wydawnictwo Akademii Ekonomicznej w Krakowie, Kraków 2006.

[12] Lockhart Hugh E., A Paradigm for Packaging, "Packaging Technology and Science" 1997, 10(5).

[13] Mynarski S., Analiza danych rynkowych i marketingowych z wykorzystaniem programu STATISTICA, Wydawnictwo Akademii Ekonomicznej w Krakowie, Kraków 2003.

[14] Rozporządzenie Parlamentu Europejskiego i Rady UE nr 1169/2011 z 25 października 2011 roku w sprawie przekazywania konsumentom informacji na temat żywności (Dz. Urz. UE nr 304/25).

[15] Stanimir A., Analiza korespondencji jako narzędzie do badania zjawisk ekonomicznych, Wydawnictwo Akademii Ekonomicznej we Wrocławiu, Wrocław 2005.

[16] Szymczak J., Ankiel-Homa M., Opakowanie jednostkowe produktów jako narzędzie komunikacji rynkowej, Marketing i Rynek" 2007, nr 6.

[17] Tomaszewska-Pielacha M., Ozimek I., Czytelność, zrozumiałość i kompletność informacji zamieszczanych na opakowaniach żywności w opinii konsumentów, „Problemy Higieny i Epidemiologii" 2011, 92(4).

[18] Wierzejska R., Informacje żywieniowe na opakowaniach produktów spożywczych - podejście konsumentów, „Przemysł Spożywczy” 2012, 66(5).

[19] Zaborski A., Skalowanie wielowymiarowe w badaniach marketingowych, Wydawnictwo Akademii Ekonomicznej we Wrocławiu, Wrocław 2001.

\section{LIMITATIONS OF COMMUNICATIVE FUNCTION OF FOOD PRODUCTS PACKAGING USED BY THE OLDER CONSUMER}

In today's competitive food market packaging fulfills a special role in terms of communicating with the consumer. Packaging performs the function of communicating mainly through the visual layer, which consists of signs forming a code package, i.e. the shape, form design, material, size, type of closure, color, subtitles and graphics. The law indicates a set of information that must be found on the packaging of the food and their physical appearance ensures readability, visibility and understandability of information. The fulfillment of legal requirements regarding the physical appearance of information is not always a guarantee of proper performance of the package communicative function. The limitation in this regard may be, e.g. specific features of the consumer in the elderly, which make it difficult or impossible to properly locate, read and understand the information placed on the packaging. The article presents the results of research on the identification of 
problems of older consumers with the usage of food packaging. Particular attention was paid to the most frequently pointed information problems by older consumers in the field to find, read and understand such information. The study was conducted using two methods: the questionnaire and the method of Eyetracking. The analysis of the results allowed identifying the sources of problems with searching, reading and understanding the information placed on the packaging of food products by identifying these problems in relation to the characteristics describing the respondents as well as by the perception of individual elements of the package by the consumer in old age.

Keywords: packaging, food product, older consumer, labeling, communicative function

\section{DOI: $10.7862 /$ rz.2016.mmr.34}

Tekst złożono w redakcji: kwiecień 2016

Przyjęto do druku: sierpień 2016 
